\title{
A social accounting matrix for Iraq
}

\author{
Dario Debowicz ${ }^{*}$ (1)
}

${ }^{*}$ Correspondence:

Dariodebowicz@gmail.com

Swansea University, Haldane

Building, Singleton Park,

Swansea, UK

\begin{abstract}
This paper deals with the challenges associated with the generation of a social accounting matrix (SAM) in conditions where up-to-date measured data are particularly scarce and provides future researchers of economic systems with the first SAM for Iraq. It delivers a unique and updated countrywide database for use in modeling and policy analysis and applies this database to the empirical investigation into the expected effects of economic diversification in Iraq as stated in the recent Iraq National Development Plan 2013-2017.
\end{abstract}

Keywords: Social accounting matrix (SAM), Semi-input-output analysis, Iraq, Economic system

\section{Background}

Iraq is an oil-exporting economy with a GDP per capita of around 6500 USD and a low inflation rate (below $2 \%$ in 2014), which attracts more than 1 billion dollars a year in foreign direct investment. However, the economy is strongly dependent on its oil sector, and almost a quarter of its population is poor (Table 1; Fig. 1). The increasing perception of oil dependency as a structural problem of the economy has recently led the international community to support efforts for an inclusive diversification of the economy (IMF 2015). To assess the expected quantitative effects of such a diversification effort on its economy, we need a social accounting matrix (SAM) for the country.

From their inception, SAMs have been instrumental in considering how different counterfactuals can affect the economy in terms of its total production, the participation of different sectors and production factors in its value added, its pattern of international trade, and the distribution of income among its institutions. SAMs record the transactions that take place in an (usually national) economy during a period of time (usually a year). As documented by Kehoe (1996), the origin of SAMs can be traced back at least until Quesnay's (1759) Tableau économique. Subsequent contributions from Kuznets (1937), Leontief (1941), and Meade and Stone (1941) paved the ground for Stone (1947) to set the main conventions for social accounting, embedded in the United Nations System of National Accounts that is used until present.

Against this historical background, the first SAM was generated by the Cambridge Growth Project (Stone et al. 1962) and was used to inform the Cambridge Growth model (Stone and Brown 1962), which in turn allowed investigating the implications 
Table 1 Macro-indicators of Iraq-2014. Source: IMF Article IV (2015)

\begin{tabular}{ll}
\hline Indicator & 2014 \\
GDP (billion dollars) & 223.5 \\
Exports of goods (\% of GDP) & 37.4 \\
Imports of goods (\% of GDP) & 30.9 \\
Trade balance (\% of GDP) & 6.6 \\
Foreign direct investment (billion dollars) & 1.0 \\
Consumer price inflation (\%) & 1.6 \\
Population (millions, 2013) & 33.4 \\
GDP per capita (USD) & 6520 \\
Poverty rate (\%, 2013) & 23.0 \\
\hline
\end{tabular}

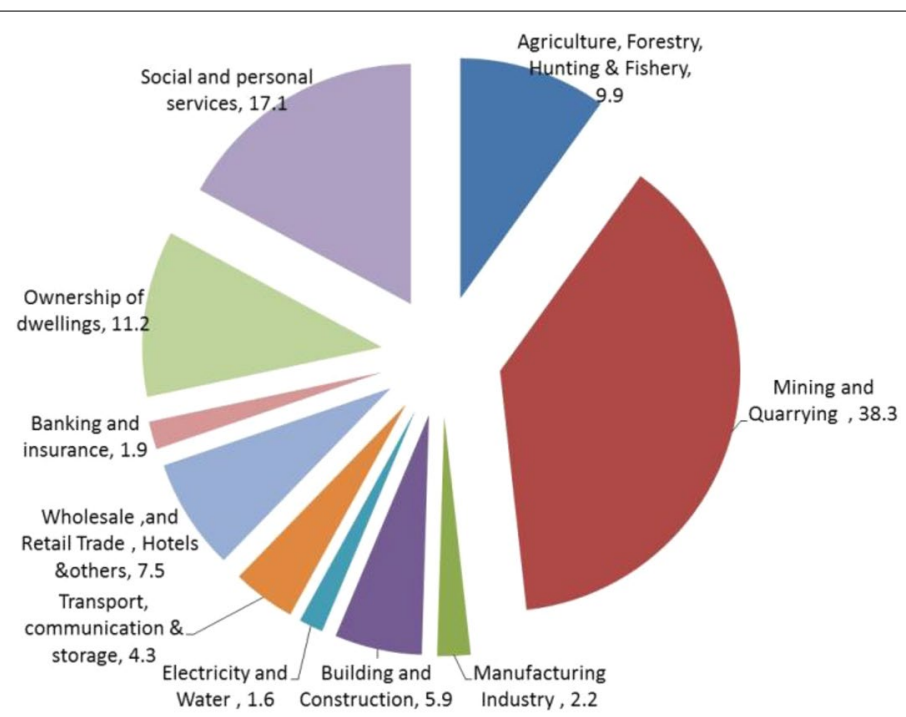

Fig. 1 Sector shares in Iraq's value added 2012. Source: author's based on CSO (2013)

of different growth strategies in the UK with assumptions that diverged from the wellestablished neoclassical paradigm (Ramanathan 1982). As documented by Round (2003), SAMs were then "further developed and used to help address poverty and income distribution issues in developing countries" by many researchers. In particular, after the seminal work conducted by Pyatt and Thorbecke (1976) at the ILO, a large number of SAM-based multiplier studies followed, some of the earliest being for Sri Lanka (Pyatt and Round 1979), Botswana (Hayden and Round 1982), Korea (Defourny and Thorbecke 1984), Indonesia (Thorbecke et al. 1992) and, more recently, Ghana (Powell and Round 2000) and Vietnam (Tarp et al. 2002). In all of these studies, the aim has been to examine the nature of the multiplier effects of an income injection in one part of an economic system on the economic structure and the functional and institutional distribution in general and on the incomes of socioeconomic groups of households in particular. More recently, SAMs were extended to account for environmental issues, including for developing economy settings such as Indonesia (Resosudarmo and Thorbecke 1996), China (Xie 2000), and Brazil (Lenzen and Schaeffer 2004). 
The economy of Iraq lacks a SAM, making it difficult-if not impossible-to assess in a quantitative way the expected countrywide effects of relevant counterfactuals such as the diversification strategy proposed by the recent Iraq National Development Plan 2013-2017 (IMoP 2013), or different scenarios regarding conflict in the country. This paper seeks to fill this gap. The novelty of the work is not on analytical methods, but on dealing with the challenges associated with a particular application of SAM generation in a context where up-to-date measured data are scarce. Our paper is organized in the following ways. In Sect. 2, we explain our approach to estimating the SAM for Iraq based on the best available information, which includes the use of sensitivity analysis to assess the role of uncertainty in the measurement of its underlying data, in Sect. 3, we analyze the structure of the Iraqi economy based on the resulting SAM, in Sect. 4, we consider the effects of the present government's economic diversification strategy via conducting a SAM-based semi-input-output analysis, and the final section concludes.

\section{Methodology for generating the SAM for Iraq}

\subsection{Design of the SAM}

The SAM for Iraq takes account of a variety of payments among its economic actors. As usual, the payments in the SAM go from columns to rows, as listed in Table 2. Consistently with the high relevance of oil extraction in the generation of value added in Iraq and the emphasis on agriculture of the Iraq National Development Plan 2013-2017 (IMoP 2013), the disaggregated set of production sectors in the SAM identifies crude oil separately from other production and provides significant detail on agriculture. ${ }^{1}$ To allow future researchers of the Iraqi economic structure to conduct a detailed analysis of the functional distribution of income and allow looking into gender issues, the production factors are disaggregated into land, capital (separated into agricultural, oil, and rest), and labor, separated by gender and three skill levels: unskilled (who did not finish primary school), semiskilled (who finished primary but not secondary school), and skilled (who finished secondary school). Finally, to capture interestingly different characteristics of households' incomes and expenditures patterns and the particularly disfavored group of female-headed households in the country (UN 2013), we disaggregate households according to urban versus rural status, region of residence (Baghdad, Kurdistan and other governorates), female-headed household status, and quintiles of per capita expenditure. Given the reduced number of female-headed households in the sample, and the disadvantaged characteristic of this group as a whole, these households are split only according to region and urban status but not according to per capita expenditure quintile. While the presence of religious-related conflict in Iraq makes disaggregating households by religion (Shia, Sunni, and Kurd) potentially interesting as a devise to look into the differences in their pattern of incomes and expenses, the lack of availability of the needed data precludes us to do so.

\subsection{Estimation of the SAM}

To estimate the cells of the SAM, we follow a series of major steps that leads to an estimated macro-consistent and disaggregated SAM for a countrywide economy. Table 3

${ }^{1}$ For a detailed description of the information used and steps followed and to access the final SAM for Iraq, please see Debowicz (2013). 


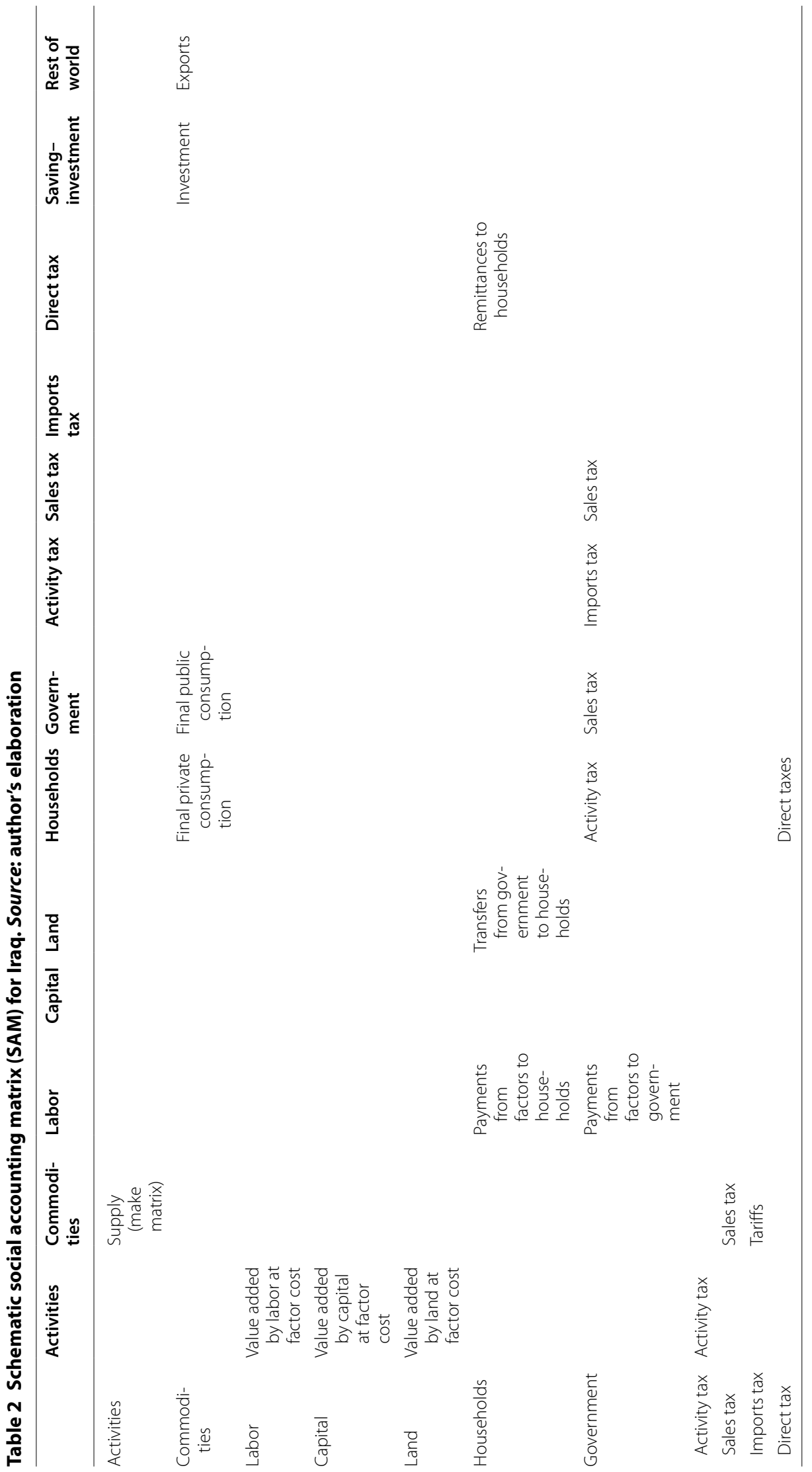




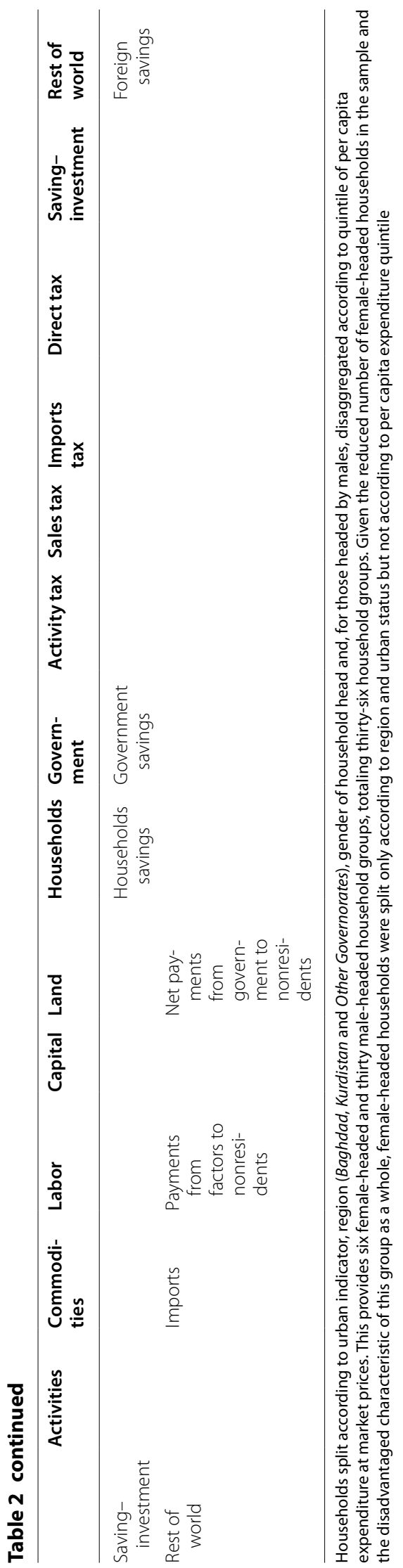




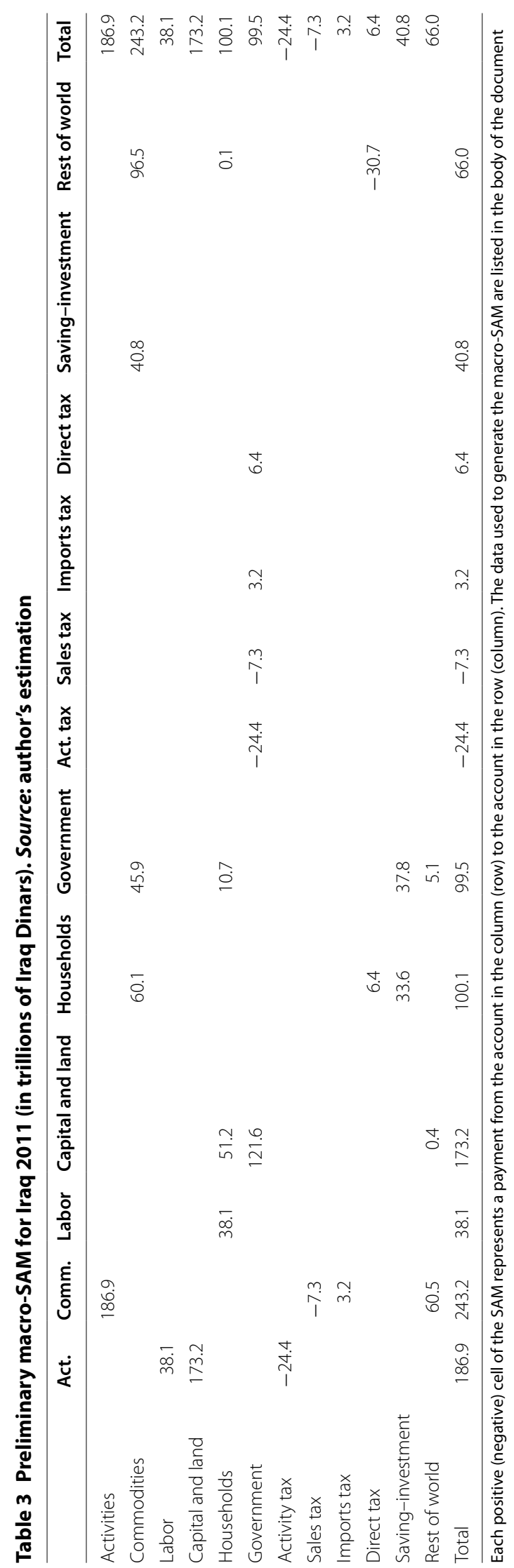


shows the numerical macro-SAM for 2011 that we obtain for Iraq, in domestic currency. The resulting macro-SAM highlights that Iraq has twin (fiscal and external) surplus and a particular low share of private consumption in total domestic production (28.4\%). It also shows the significant activity and commodity subsidies implemented by the Iraqi government (24.4 and 7.3 trillions of Iraq Dinars, respectively).

We explicitly consider the higher uncertainty that is arguably present in the underlying data of the transactions matrix. As a recent study mentions, "in general practice, only a minor proportion of authors actually add uncertainty analysis to their input-output case studies" (Lenzen et al. 2010, p. 44). Given information on the uncertainty of the components of the SAM and using simulation methods, researchers are able to provide estimates of the uncertainty attached to their cells. While the available data for Iraq are silent in regard to measured uncertainty, given that the underlying input-output matrix dates back to 1988, the uncertainty associated with the transactions matrix is arguably above the rest of the information underlying the SAM. Reflecting this, we carry out sensitivity analysis on the standard deviation of the cells in the transaction matrix. In order to assess the role that the higher uncertainty on the transactions matrix of Iraq may be playing in the generation of the resulting SAM, and given the absence of data on the standard deviation of the point estimations publicly provided, we conduct sensitivity analysis. In particular, we assume that the standard deviation of the error with which the data in the transaction matrix are observed is much higher than that of the rest of the matrix. We increase the standard deviation of the additive errors for the cells located in the transaction matrix first by $50 \%$ and then by $100 \%$. As shown in Figs. 2, 3, and 4, while this experiment does increase the balancing changes in the transactions matrix, the increases are rather small, providing further evidence of the validity of the resulting matrix.

\section{Structure of the Iraq economy and multiplier analysis}

The structure of the Iraq economy in terms of its aggregate demand composition-listed in Table 4-confirms the stylized facts commented at the beginning of the analysis in light of the macro-SAM. Iraq export value exceeds substantially its import value, leading to a significant trade superavit of 36 trillions of Iraq Dinars, or $19.3 \%$ of its GDP (gross domestic product) at market prices. The participation of private consumption in GDP is only $46.8 \%$, a reflection of the high relation between the fiscal and current account surplus, on the one hand, and the gross domestic product, on the other hand. Table 4 also shows the sizable indirect subsidies existent in the Iraqi economy, which exceed indirect taxes in 25 trillions of Iraq Dinars, that is, more than $13 \%$ of its GDP at market prices.

The domestic production of Iraq is clearly dominated by oil, leaving agriculture and other industry with relatively low participation in the generation of domestic value added (Table 5). The production of crude oil accounts for almost half of the value added of the economy $(47.9 \%)$. Almost all the crude oil that is extracted in Iraq is exported $(99.8 \%)$, allowing the sector to explain the vast majority of the country's export value $(98.0 \%)$, as well as the main source of finance for the public sector. ${ }^{2}$ Around $40 \%$ of the value added in the country is generated by (non-traded) services, a significant part of

2 The oil sector in Iraq is characterized by the preeminence of the state (Iraq National Development Plan 2013-2017, p. 59). 


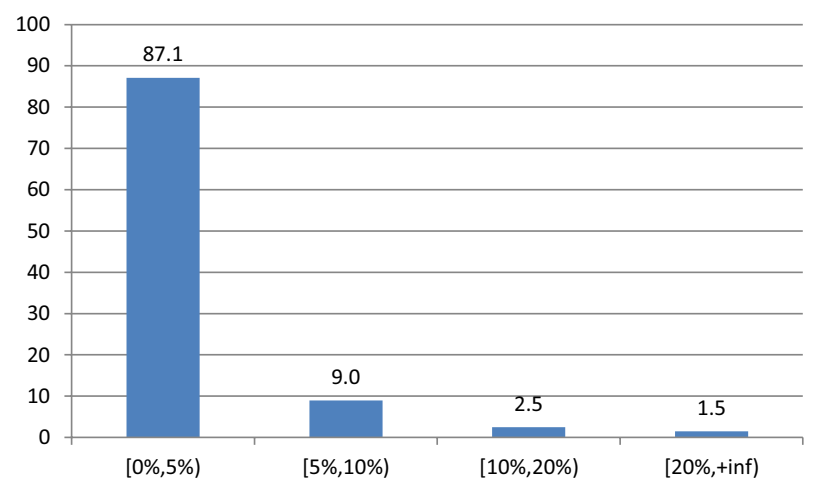

Fig. 2 Histogram of absolute value of percentage differences generated in the transactions matrix by crossentropy balancing process. Source: author's based on Table A5. Heights reflect number of cells changing as stated in category as percentage of total nonzero cells in the transactions matrix (201). Percentages are rounded at one decimal point

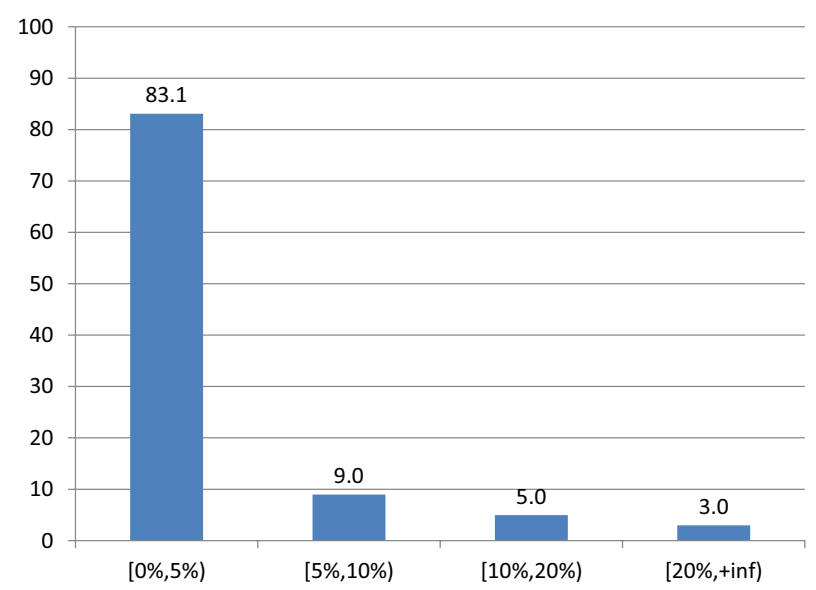

Fig. 3 Histogram of absolute value of percentage differences generated in the transactions matrix by crossentropy balancing process - SDs in additive errors increased $50 \%$. Source: author's calculation. Heights reflect number of cells changing as stated in category as percentage of total nonzero cells in the transactions matrix (201). Percentages are rounded at one decimal point

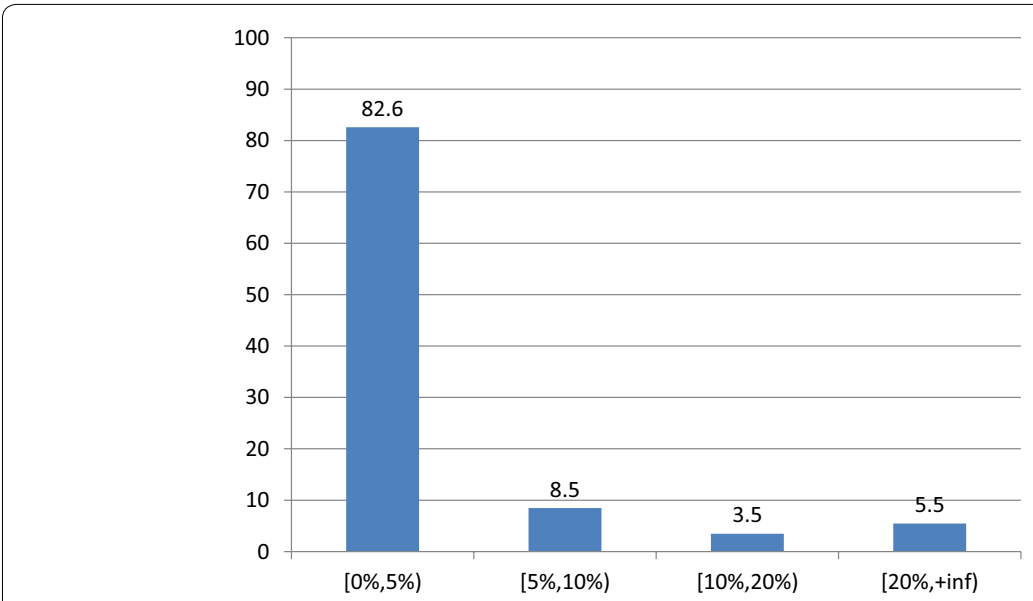

Fig. 4 Histogram of absolute value of percentage differences generated in the transactions matrix by crossentropy balancing process-SDs in additive errors increased $100 \%$. Source: author's calculation. Heights reflect number of cells changing as stated in category as percentage of total nonzero cells in the transactions matrix (201). Percentages are rounded at one decimal point 
Table 4 Gross domestic product and aggregate demand components (trillions of Iraq Dinars and percentage of GDP). Source: author's elaboration based on social accounting matrix for Iraq 2011

\begin{tabular}{lcc}
\hline & $\begin{array}{l}\text { Trillions of Iraq } \\
\text { Dinars }\end{array}$ & $\begin{array}{l}\text { Share of GDP } \\
\text { at market prices }\end{array}$ \\
\hline Domestic absorption & 150.3 & 80.7 \\
Private final consumption & 87.2 & 46.8 \\
Fixed investment & 37.7 & 20.2 \\
Public final consumption & 25.5 & 13.7 \\
Exports & 96.5 & 51.8 \\
Imports & -60.5 & -32.5 \\
Gross domestic product at market prices & 186.3 & 100.0 \\
Net indirect taxes & -25.0 & -13.4 \\
Gross domestic product at factor cost & 211.3 & 113.4 \\
\hline
\end{tabular}

Domestic absorption equals the sum of private final consumption, fixed investment, and public final consumption. Gross domestic product at factor cost equals gross domestic product at market prices minus net indirect taxes, which in the case of Iraq are negative, given that indirect subsidies exceed indirect taxes. Private (public) final consumption captures the sum of the payments from households (government) to commodities in the SAM. Fixed investment (exports) captures the sum of the payments from the saving-investment (rest of world) account to commodities in the SAM. Imports capture the sum of the payments from the commodities account to the rest of world account in the SAM. Net indirect taxes captures the sum of the payments (some of which are negative) from the sales tax and tariff accounts to the government account

Table 5 Economic structure: sector shares in value added, domestic absorption, exports and imports. Source: author's elaboration based on social accounting matrix for Iraq 2011

\begin{tabular}{lccrrll}
\hline Sector & Value added & Absorption & Export & Import & Export intensity & Import intensity \\
\hline Crops & 9.1 & 16.3 & 0.1 & 11.7 & 0.003 & 0.131 \\
Livestock & 0.6 & 4.0 & & 3.0 & & 0.139 \\
Crude & 47.9 & 0.0 & 98.0 & & 0.998 & \\
Other mining & 1.4 & 2.3 & 0.1 & 0.1 & 0.012 & 0.005 \\
Oil refining & 0.5 & 1.1 & 0.8 & 3.9 & 0.349 & 0.640 \\
Processed food & 0.3 & 14.4 & & 16.5 & & 0.207 \\
Other manufacturing & 1.4 & 13.7 & 0.9 & 64.0 & 0.112 & 0.849 \\
Electricity and water & 1.7 & 1.8 & & 0.1 & & 0.015 \\
Construction & 5.3 & 7.8 & & 0.7 & & 0.017 \\
Trade & 6.8 & 5.1 & & & & \\
Transport & 3.7 & 5.9 & & & & \\
Financial services & 2.0 & 1.3 & & & & \\
Housing & 7.9 & 5.5 & & & & 0.182 \\
Public services & 11.5 & 20.8 & & & & \\
Total & 100.0 & 100.0 & 100.0 & 100.0 & 0.252 & \\
\hline
\end{tabular}

Domestic absorption is the sum of domestic intermediate consumption plus domestic final consumption, domestic investment, and domestic public consumption. Export intensity: ratio between export and output value. Import intensity: ratio between import and domestic absorption value

which is provided by the public services. In contrast, agriculture and industry generate less than $15 \%$ of the domestic value added and have negative international trade positions.

As listed in Table 6, the share of capital in domestic income is nearly three times that of labor (73.3 vs. $24.0 \%$ ), leaving labor with a share of domestic income that is strikingly low at international level (Karabarbounis and Neiman 2013). This high participation of capital in the domestic income is explained by the combination of a high participation of 
Table 6 Composition of value added (percentages). Source: author's elaboration based on social accounting matrix for Iraq 2011

\begin{tabular}{lcccc}
\hline & Labor & Capital & Land & Total \\
\hline Agriculture & 62.0 & 9.7 & 28.3 & 100.0 \\
Crops & 64.3 & 7.1 & 28.6 & 100.0 \\
Livestock & 27.4 & 48.4 & 24.2 & 100.0 \\
Industry & 3.2 & 96.8 & & 100.0 \\
Crude & 0.9 & 99.5 & 100.0 \\
Other mining & 0.7 & 99.3 & 100.0 \\
Oil refining & 15.8 & 84.2 & 100.0 \\
Processed food & 48.1 & 51.9 & & 100.0 \\
Other manufacturing & 84.1 & 15.9 & & 100.0 \\
Services & 42.0 & 58.0 & & 100.0 \\
Electricity and water & 61.6 & 38.4 & & 100.0 \\
Construction & 60.5 & 39.5 & & 100.0 \\
Trade & 10.1 & 89.9 & & 100.0 \\
Transport & 37.0 & 63.0 & & 100.0 \\
Financial services & 91.0 & & 100.0 \\
Housing & & 100.0 & & 100.0 \\
Public services & 85.5 & 14.5 & 2.7 & 100.0 \\
Total & 24.0 & 73.3 & 100.0 \\
\hline
\end{tabular}

Each cell is informed by the ratio between the payments in the SAM from the sector in the row to the factor in the column and those from the sector in the row to all the production factors present in the SAM (labor, capital, and land)

mining in domestic value added and a high share of capital in the distribution of mining income, where only half of a percentage point of value added is used for remunerating labor. The heterogeneity in the value-added share of labor among the Iraqi sectors is significant, going from 0.5 to $07 \%$ (oil and other mining) to $64.3 \%$ (agricultural crops).

Iraq has a relatively urbanized population, with 21.5 out of 30.3 million inhabitants, or $71 \%$, located in urban areas (Table 7 ), and 7.1 million inhabitants $(23.5 \%)$ residing in Baghdad. Households in Iraq have 6.9 inhabitants on average. This size is even larger in poor and rural areas: The household size in the bottom quintile of the rural area reaches 9.5 inhabitants on average. Households in Baghdad and Kurdistan are relatively small (6.4 and 6.1 inhabitants, on average). Per capita income is significantly higher in the urban areas: Urban inhabitants earn on average $50 \%$ more than their rural counterparts. Inequality within urban and rural areas is also high. The top per capita income quintile of the urban (rural) population gets 3.9 (3.7) times the figure for their bottom quintile counterparts.

Public transfers account for a measurable fraction of the income of the households, especially in the female-headed ones, where they explain nearly $18 \%$ of total household income. More than three-fourth of household income (78.2 \%) is earned by urban households (last column of Table 8). Compared to rural households, urban households get significantly higher per capita income (as shown above), have a higher share of capital and skilled labor income (especially in the case of the wealthier households), and a lower share of land and unskilled labor income. Households in Kurdistan have a relatively high share of capital and a low share of public transfers in their income in comparison with their non-Kurdistan counterparts. 
Table 7 Income and population by representative household group. Source: author's elaboration based on social accounting matrix for Iraq 2011 and population data in IHSES 2007

\begin{tabular}{lllll}
\hline & $\begin{array}{l}\text { Income (trillion } \\
\text { ID per year) }\end{array}$ & $\begin{array}{l}\text { Population } \\
\text { (millions) }\end{array}$ & $\begin{array}{l}\text { Average } \\
\text { household size }\end{array}$ & $\begin{array}{l}\text { Per capita income } \\
\text { (thousand ID } \\
\text { per year) }\end{array}$ \\
\hline Rural female headed & 1.4 & 0.6 & 5.7 & 2496 \\
Rural quintile 1 & 6.1 & 3.9 & 9.5 & 1576 \\
Rural quintile 2 & 4.3 & 1.9 & 7.6 & 2235 \\
Rural quintile 3 & 3.5 & 1.3 & 6.9 & 2808 \\
Rural quintile 4 & 3.0 & 0.8 & 6.1 & 3816 \\
Rural quintile 5 & 2.5 & 0.4 & 5.2 & 5821 \\
Urban female headed & 8.6 & 2.3 & 5.9 & 3693 \\
Urban quintile 1 & 6.5 & 3.6 & 9.0 & 1827 \\
Urban quintile 2 & 9.5 & 4.2 & 7.7 & 2286 \\
Urban quintile 3 & 12.2 & 4.3 & 7.0 & 2875 \\
Urban quintile 4 & 14.8 & 3.9 & 6.0 & 3778 \\
Urban quintile 5 & 23.2 & 3.3 & 5.0 & 7097 \\
Urban & 74.8 & 21.5 & 6.6 & 3485 \\
Rural & 20.8 & 8.8 & 7.7 & 2362 \\
Baghdad & 22.4 & 7.1 & 6.4 & 3162 \\
Kurdistan & 21.0 & 3.9 & 6.1 & 5403 \\
Other governorates & 52.2 & 19.3 & 7.3 & 2703 \\
Total & 95.6 & 30.3 & 6.9 & 3158 \\
\hline The & & & &
\end{tabular}

The income column was generated by the sum of the incomes received by each of the household groups and their aggregates (e.g., urban households). The population for each group of households is provided by multiplying the row vector of number of individuals in the households by the column vector of expansion factors for each household. Average household size obtained dividing population by number of households in each household group, accounting for expansion factors. Per capita income (thousand ID per year) obtained dividing income (trillion ID per year) by population (millions) and multiplying by $10^{-3}$

Controlling for the income level, the share of food (crops, livestock and processed food) in the total consumption value of the households tends to be higher in rural areas (for the same income quintile), and the share of services is systematically higher in urban areas (Table 9). Our SAM suggests that the Engel law is valid for Iraq: As we move into household groups with higher per capita expenditure, the share of food in total expenditure tends to go down, both in rural and urban areas.

Finally, even when the number of production factors in the SAM is significantly below the number of sectors and households, the SAM does capture factor income and expenditure patterns that are quite different among the ten production factors present in the SAM. As Fig. 5 shows, there are particularly high differences in the composition by source of factor earnings in the oil and the public services sector: The oil-specific capital stock derives all its income from the oil sector, while other factors (e.g., agricultural capital) have no income in that sector; most of the income (81.5\%) of the (few) skilled women comes from work in the public sector, while other factors earn no income in this sector (e.g., oil-specific capital). As Fig. 6 suggests, the allocation of factor expenditures among institutions is also quite different among factors. Given that the income earned by oil capital is captured by the government, any shock affecting this sector will tend to change significantly the income distribution among factors and among institutions. The mentioned differences in factor income and expenditure patterns suggest that the present SAM is not particularly affected by distribution invariance (Pyatt and Round 2012). 


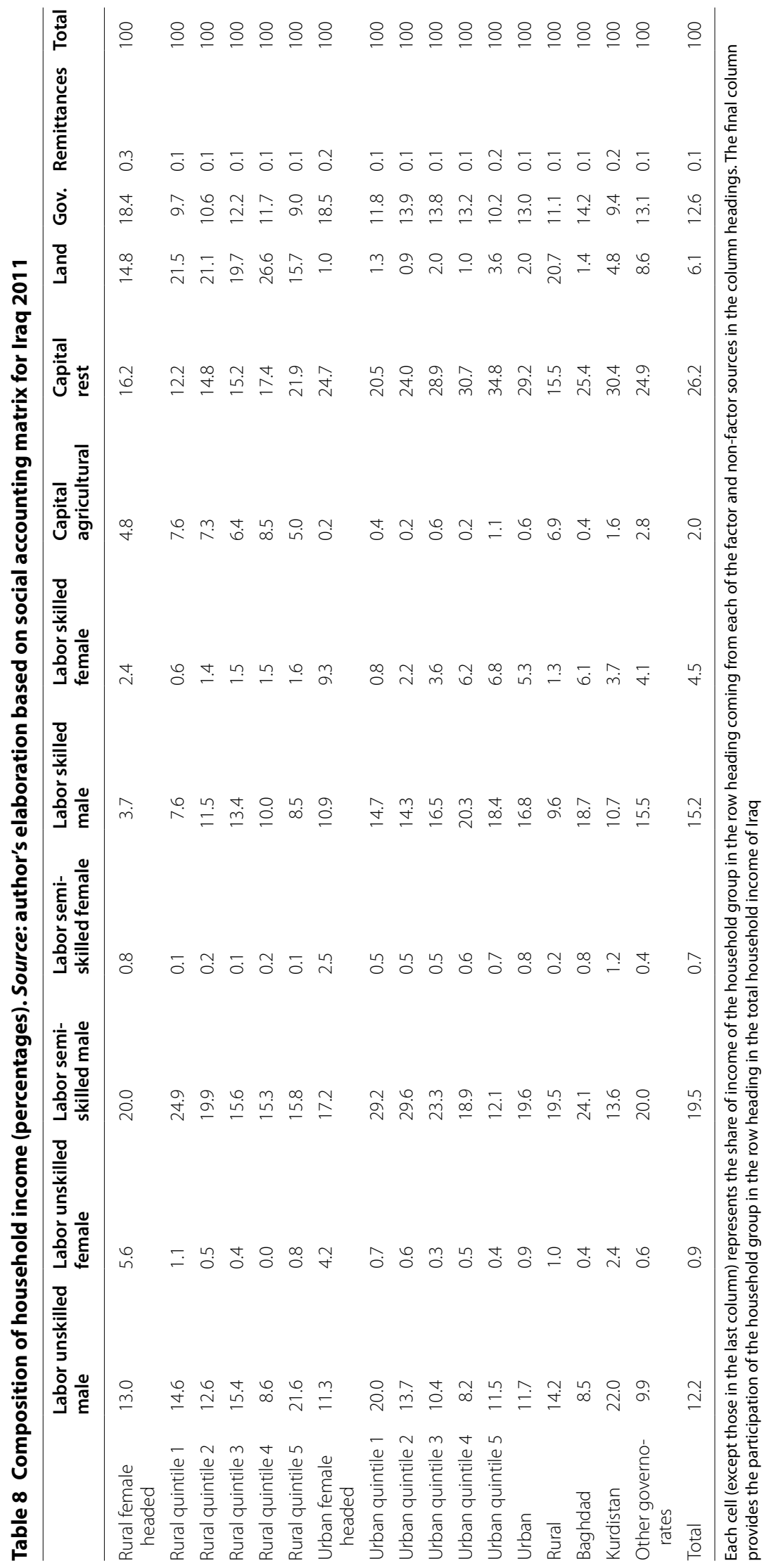




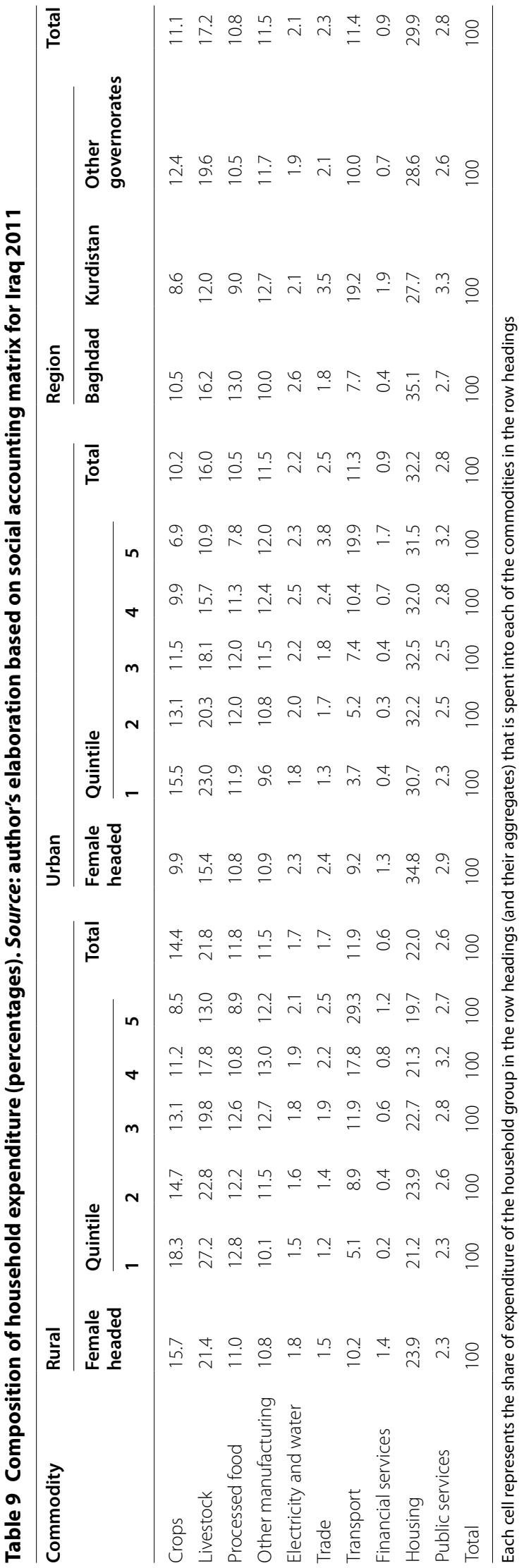




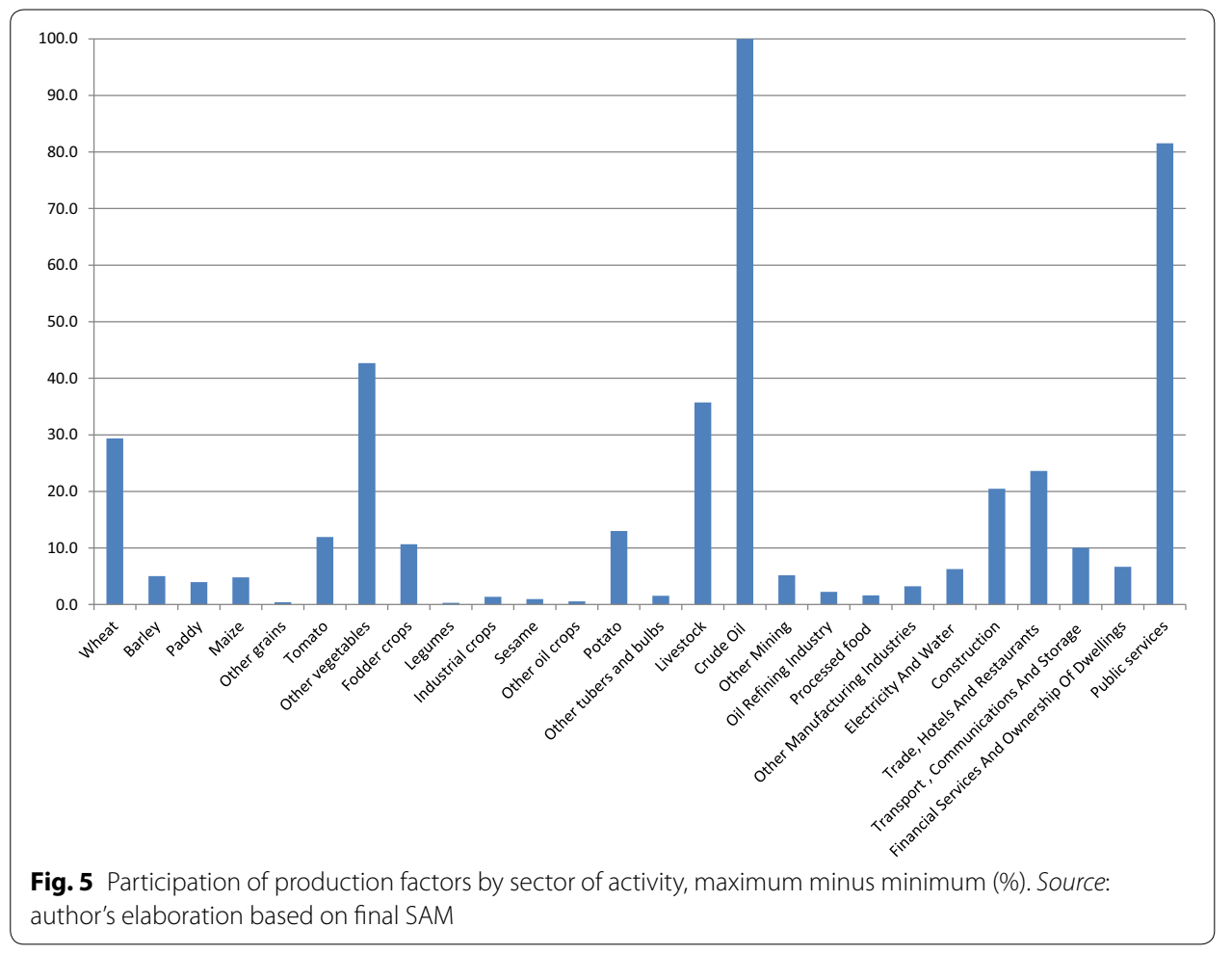

To finalize the observations on the SAM, we provide its associated multipliers, jointly accounting for direct, indirect, and induced effects. For this, consistently with the following section, which focuses on the National Development Plan of Iraq, we split the economy into agriculture, crude oil, other industry, and services (Table 10). The income multiplier of oil is the highest one. Since this multiplier reflects the ratio of the change in total income earned by workers in all sectors of the economy to the change in earnings of workers directly engaged in the extraction of crude oil, what this is actually capturing is the relatively low share of labor earnings per unit of output in the extraction of crude oil, a stylized fact of the sector. More interestingly, the value-added multiplier of other industry is not only very high in absolute terms (11.3), but also more than double than the value-added multiplier of any other sector, making it an interesting avenue for the diversification of the economic structure that the present National Development Plan of Iraq has in its core.

\section{The 2013-2017 Iraq National Development Plan}

With significant support from international organizations and bilateral donors, the Government of Iraq has recently designed a National Development Plan for 2013-2017. In its strategic document (IMoP 2013), the Government of Iraq diagnoses the country as "a revenue-generating economy dependent on a single resource, oil" (page v) and commits "to expanding its base to depend on other activities" (page v), "with industry, energy, agriculture and tourism as the main drivers and pillars of development" (page 58). The Plan is silent regarding the effects of relying on these drivers, either on the resulting production structure once the interrelations among the production sectors are taken into 


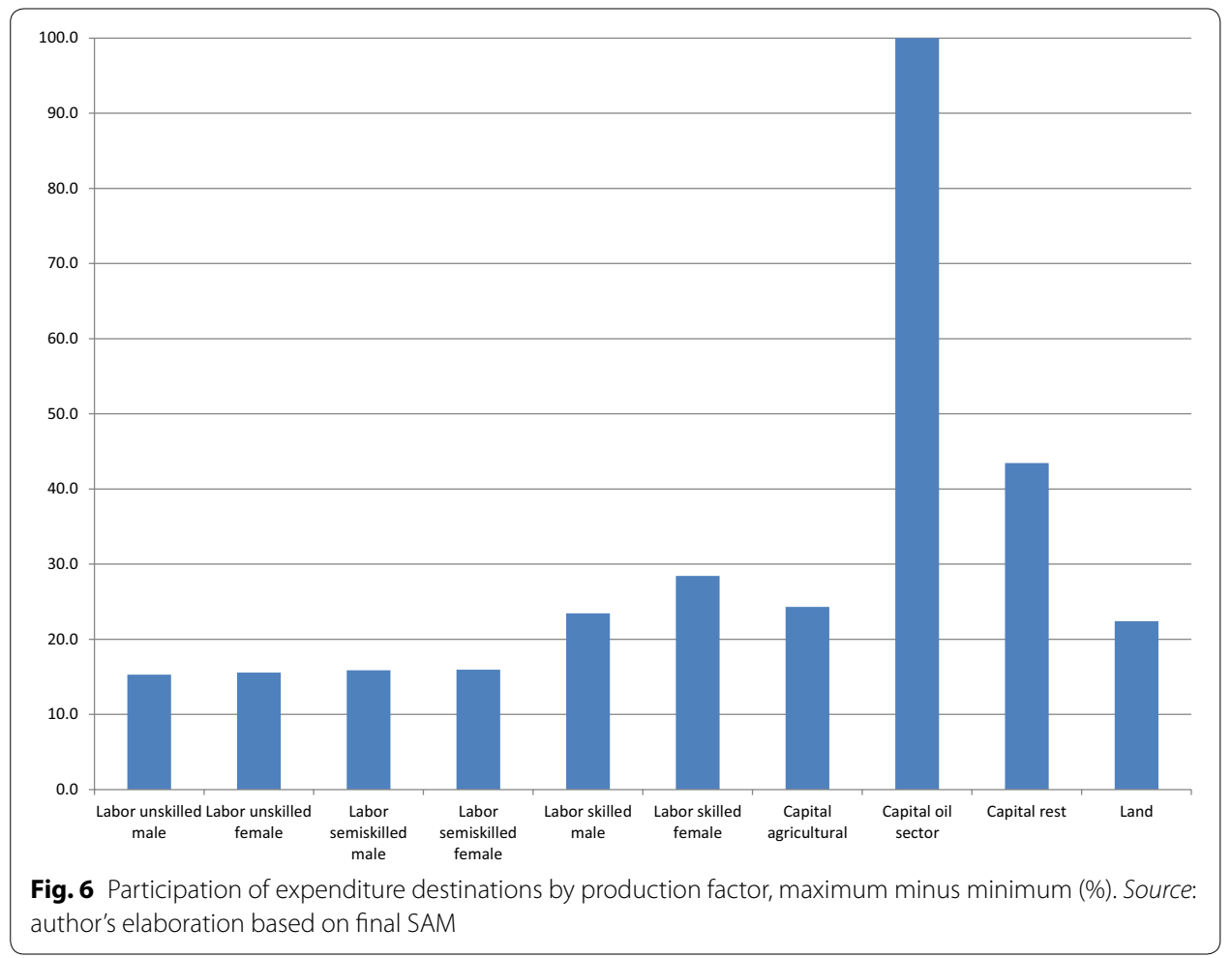

Table 10 Type 2 multipliers for the social accounting matrix for Iraq. Source: author's calculation

\begin{tabular}{llcc}
\hline Sector & Multiplier & Value added & Income \\
\cline { 2 - 4 } & Output & 4.7 & 4.0 \\
\hline Agriculture & 5.2 & 1.7 & 50.5 \\
Crude oil & 2.5 & 11.3 & 15.9 \\
Other industry & 5.7 & 2.9 & 3.0 \\
Services & 4.6 & &
\end{tabular}

account, or on incomes of different household groups. Relying on a semi-input-output model, with constrained linear relationships among quantities in the model and fixed prices, and where the supply-constrained sectors are identified as the tradable goods, ${ }^{3,4}$ we consider these effects in light of the estimated SAM, providing potentially valuable information on the economic effects of the Plan.

Considering the size of the economy of Iraq, we simulate a monetary injection of 20 trillion Iraq Dinars at constant prices of 2011-i.e., slightly less than $10 \%$ of GDP-to the economy. Reflecting the driving sectors in the Plan, we run four simulations, with the injection: (1) focused on agriculture; (2) focused on oil extraction; (3) focused on

\footnotetext{
${ }^{3}$ Namely: Wheat, barley, paddy, maize, other grains, other vegetables, fodder, industrial crops, oil crops, tubercles, livestock, crude oil, other mining, oil refining, food processing, other manufacturing, construction, and electricity.

4 The inclusion of relative price changes potentially generated by these simulations would require setting up a computable general equilibrium (CGE) model and is out of the scope of the present research.
} 
industry (excluding crude oil extraction); and (4) combining the mentioned sectors. ${ }^{5,6}$ In each sector of the SAM, the injection is directed either to domestic supply (for supplyconstrained sectors) or to net exports demand (for supply-flexible sectors), with the latter affecting in turn the sectors' endogenous supply. We consider two policy-relevant questions in particular: (1) is one of these injections particularly good at broadening the production base, as measured by the size of the non-oil extraction sector? and (2) is one of these injections particularly good at improving the income of the more disfavored-in terms of their original per capita income-groups of households?

Table 11 shows the resulting value added for broad sectors, both in terms of value (trillions of Iraq Dinars) and in terms of share of total value added (percentage), and Table 12 shows the resulting income changes for aggregated household groups, as percentage of their pre-simulated income. We find that, while the injection in the oil extraction sector is the one that achieves the maximum increase in the economy's value added (19.7 trillion of Iraq Dinars), due to the weak backward linkage of this sector with unconstrainedsupply sectors in the domestic economy, it ends up significantly reducing the share of the non-oil sector in the economy (by $4.1 \%$ points, from 52.1 to $48.1 \%$ ), against the diversification goal of the Plan. In contrast, the agricultural and the industrial injections result in a significant increase in the production of services (particularly, domestic trade services increase by $19.1 \%$ with the agricultural-focused injection and $25.8 \%$ with the industry-focused injection, and domestic banking services increase by 8.6 and $10.8 \%$, respectively ${ }^{7}$ ) and hence result in a significant final increase in the share of the non-oil sector in the economy's value added ( $3.1 \%$ points). The industry-focused simulation leads to a relatively larger service sector, reflecting relatively high direct requirements of non-tradable services by the industrial sector. The combined injection leads to a significant increase in the value added of the oil sector (14.5\%), which has relatively low input requirements from other sectors. The increase in the value added of the non-oil sector, which relies to a larger extent on imports to satisfy its production requirements, is significantly smaller $(3.5 \%)$. The results suggest then that a combined injection as the one suggested by the National Development Plan runs the risk of ending up generating a significant reduction in the participation of the non-oil sector in the economy, in the order of $2.5 \%$ points.

The agricultural injection significantly increases average household income in Iraq (by $11.6 \%$ ), by a proportion that exceeds the ratio between the injection and the value added of the economy (below $10 \%$ )-reflecting the relative detachment of household income from the generation of value added in the oil extraction sector commented in Sect. 2, a structural characteristic of the economy, and exceeding the effect on household incomes of the other simulated injections. Given the low participation of factors owned by households into the production of oil and the low domestic input requirements of the oil sector, the oil-focused injection and the combined injection lead to particularly small increases in average household income (0.6 and $2.9 \%$, respectively). In contrast, both

\footnotetext{
5 The distribution of the simulated injection among the sectors in the SAM follows that of value added on the sectors under focus. For example, in the agricultural-focused simulation, livestock receives $6.1 \%$ of the injection, following the proportion of value added in Table 5 ( 0.6 out of 9.7).

${ }^{6}$ An injection in the tourism sector is not simulated due to the lack of feasibility of developing the tourism sectors in the present country's security context and also due to lack of associated disaggregated data.

7 Not tabulated.
} 
Table 11 Simulated value added by broad sectors (trillions of Iraq Dinars and share of total). Source: authors' semi-input-output analysis

\begin{tabular}{|c|c|c|c|c|c|c|c|c|c|c|}
\hline & \multicolumn{2}{|l|}{ Base } & \multicolumn{2}{|c|}{$\begin{array}{l}\text { Injection } \\
\text { in agriculture }\end{array}$} & \multicolumn{2}{|c|}{$\begin{array}{l}\text { Injection } \\
\text { in crude oil }\end{array}$} & \multicolumn{2}{|c|}{$\begin{array}{l}\text { Injection } \\
\text { in other indus- } \\
\text { try }\end{array}$} & \multicolumn{2}{|c|}{$\begin{array}{l}\text { Combined } \\
\text { injection }\end{array}$} \\
\hline & Value & $\%$ & Value & $\%$ & Value & $\%$ & Value & $\%$ & Value & $\%$ \\
\hline Agriculture & 20.5 & 9.7 & 28.5 & 12.6 & 20.5 & 8.9 & 20.7 & 9.2 & 21.8 & 9.5 \\
\hline Crude oil & 101.2 & 47.9 & 101.2 & 44.8 & 120.0 & 51.9 & 101.2 & 44.8 & 115.9 & 50.4 \\
\hline Other industry & 7.5 & 3.5 & 7.5 & 3.3 & 7.5 & 3.2 & 14.2 & 6.3 & 7.9 & 3.4 \\
\hline Services & 82.1 & 38.9 & 88.9 & 39.3 & 83.0 & 35.9 & 89.6 & 39.7 & 84.3 & 36.7 \\
\hline Non-oil subtotal & 110.1 & 52.1 & 124.9 & 55.2 & 111.0 & 48.1 & 124.4 & 55.2 & 114.0 & 49.6 \\
\hline Total & 211.3 & 100 & 226.1 & 100 & 231.0 & 100 & 225.6 & 100 & 229.9 & 100 \\
\hline
\end{tabular}

Table 12 Per capita income by household groups, base levels (thousand of Iraq Dinars per year) and simulated changes (\%). Source: authors' semi-input-output analysis

\begin{tabular}{lcclll}
\hline Household group & Base & $\begin{array}{l}\text { Injection in } \\
\text { agriculture }\end{array}$ & $\begin{array}{l}\text { Injection in } \\
\text { crude oil }\end{array}$ & $\begin{array}{l}\text { Injection in } \\
\text { other industry }\end{array}$ & $\begin{array}{l}\text { Combined } \\
\text { injection }\end{array}$ \\
\hline Rural female headed & 2496 & 14.9 & 0.4 & 6.4 & 3.1 \\
Rural quintile 1 & 1576 & 17.7 & 0.5 & 6.4 & 3.5 \\
Rural quintile 2 & 2235 & 17.1 & 0.5 & 6.6 & 3.5 \\
Rural quintile 3 & 2808 & 16.4 & 0.5 & 6.5 & 3.4 \\
Rural quintile 4 & 3816 & 18.5 & 0.4 & 6.3 & 3.6 \\
Rural quintile 5 & 5821 & 15.5 & 0.5 & 7.8 & 3.3 \\
Urban female headed & 3693 & 9.7 & 0.6 & 8.3 & 2.5 \\
Urban quintile 1 & 1827 & 10.6 & 0.6 & 8.9 & 2.7 \\
Urban quintile 2 & 2286 & 9.8 & 0.7 & 9.1 & 2.6 \\
Urban quintile 3 & 2875 & 10.0 & 0.7 & 9.4 & 2.7 \\
Urban quintile 4 & 3778 & 9.5 & 0.7 & 9.6 & 2.6 \\
Urban quintile 5 & 7097 & 10.7 & 0.7 & 9.9 & 2.7 \\
Urban & 3485 & 10.1 & 0.7 & 9.4 & 3.5 \\
Rural & 2362 & 17.0 & 0.5 & 6.6 & 2.6 \\
Baghdad & 3162 & 9.6 & 0.7 & 9.0 & 3.0 \\
Kurdistan & 5402 & 12.1 & 0.7 & 9.4 & 2.9 \\
Other governorates & 2703 & 12.3 & 0.6 & 8.5 & 2.9 \\
Total & 3158 & 11.6 & 0.6 & 8.8 & \\
\hline
\end{tabular}

the agricultural injection and the industrial injection increase urban and rural incomes in a measurable way and significantly affect household incomes in Baghdad, Kurdistan, and other governorates. The agricultural injection, as opposed to the industrial injection, leads to increase the relative income of households groups whose original income is relatively low. The real income of rural households increases by $17 \%$, while the urban household income increases by $10.1 \%$. Household income in other governorates increases by $12.3 \%$, slightly above the national average household income increase (11.6 \%). However, the female-headed households, a group whose welfare is targeted by social policy in Iraq, find their income increasing by less than average in the agricultural-focused simulation (as well as in other simulated injections), reflecting their relatively low share of factor income-and significant incidence of public transfers-in their income composition (as 
listed in Tables 3, 4, 5), and suggesting the need for the Government of Iraq to continue implementing complementary policies to help this disadvantaged group.

\section{Conclusions}

The present study provides the first countrywide SAM for the analysis of economic counterfactuals in Iraq and a subsequent semi-input-output analysis of the potential effects of the National Development Plan of Iraq on its production structure and household incomes.

In dealing with the challenges associated with the generation of the SAM in a context where up-to-date measured data are scarce, the validity of the resulting matrix is assessed in light of stylized characteristics of the Iraqi economy, the analysis of the levels of shifts in the elements of the transactions matrix at the time of balancing the accounts of the SAM, and sensitivity analysis regarding the influence of the uncertainty in the underlying data on the resulting transactions matrix. Overall and under different assumptions regarding the uncertainty in the observed transaction matrix, the analysis suggests that the requirements to produce the different outputs in the Iraqi economy have not changed significantly from the last available input-output matrix, which is consistent with salient structural characteristics of the Iraqi economy having remaining unchanged. Having said this, looking to the future, it would be advisable for the Government of Iraq to update both the input-output matrix of the country and the present SAM in order to improve the empirical base for the analysis of the expected effects of economic policies and exogenous shocks to the economy.

The SAM-based semi-input-output analysis of the effects of the present National Development Plan of Iraq suggests that diversification efforts to expand the production base of Iraq into agriculture and non-oil industry are prone to increase significantly the relative size of the service sector, leading to a significant increase in the relative size of the non-oil sector in the economy. It also suggests that the diversification efforts will have widespread effects on households in different areas of the country and that diversifying the production base in the direction of agriculture leads to increase the relative income of the disfavored rural households. The analysis also suggests that the diversification strategy is unfortunately not prone to affect the income of the disfavored femaleheaded households in a significant way by itself and that complementary policies will continue to be needed to support this group, either in the form of direct transfers or boosting their participation in market activities.

These conclusions rely on the semi-input-output model assumption that the domestic commodity and factor markets can be equilibrated relying mainly on changes in quantities (production, consumption, and international trade) without relative price adjustments. While domestic relative prices in Iraq are linked to mostly exogenous world prices and are partly subject to state-driven price controls, future research could successfully exploit the constructed database in the implementation of a computable general equilibrium model with endogenous relative prices to assess the potential effects of economic diversification and other economic policies in Iraq. The analysis recently carried out by Al-Hahoby et al. (2016) based on this SAM provides an illustration focused on the expected effects of implementing the present National Development Plan of Iraq. 


\section{Acknowledgements}

I acknowledge financial support from the Harmonized Support for Agricultural Development USAID program at the International Food Policy Research Institute, as well as feedback received from Clemens Breisinger, Teunis van Rheenen Jenna Ferguson, and other colleagues at IFPRI and from participants of a workshop on policy modeling for Iraq coorganized by ICARDA and IFPRI in Amman, Jordan, on June 10-11, 2013. As usual, the responsibility for eventual errors and omissions is mine.

\section{Competing interests}

The author declares that he has no competing interests.

Received: 14 January 2016 Accepted: 20 September 2016

Published online: 27 September 2016

\section{References}

Al-Hahoby A, Breisinger C, Debowicz D et al (2016) The role of agriculture for economic development and gender in Iraq: a computable general equilibrium model approach. J Dev Areas 50-2:431-451

CSO (2013) Share in value added by sector 2012. Central Statistical Office of Iraq. http://cosit.gov.iq/AAS2012/ section_14/5B.htm

Debowicz D (2013) A social accounting matrix for Iraq 2011. International Food Policy Research Institute (IFPRI), Washington, DC. https://www.ifpri.org/publication/social-accounting-matrix-iraq-2011

Defourny J, Thorbecke E (1984) Structural path analysis and multiplier decomposition within a social accounting matrix. Econ J 94:111-136

Hayden C, Round J (1982) Developments in social accounting methods as applied to the analysis of income distribution and employment issues. World Dev 10:451-465

IMF (2015) Iraq Article IV. www.imf.org

IMoP (2013) National Development Plan 2013-2017. Iraq Ministry of Planning, Baghdad

Karabarbounis L, Neiman B (2013) The global decline of the labor share. NBER Working Paper 19136

Kehoe TJ (1996) Social accounting matrices and applied general equilibrium models. Working Paper 563, Federal Reserve Bank of Minneapolis, Research Department

Kuznets S (1937) National income and capital formation, 1919-1935. NBER Bulletin 66:1-15

Lenzen M, Schaeffer R (2004) Environmental and social accounting for Brazil. Environ Resour Econ 27(2):201-226

Lenzen M, Wood R et al (2010) Uncertainty analysis for multi-region input-output models-a case study of the UK's carbon footprint. Econ Syst Res 22(1):43-63

Leontief WW (1941) The structure of American economy, 1919-1929: an empirical application of equilibrium analysis. Harvard University Press, Cambridge, MA

Meade JE, Stone R (1941) The construction of tables of national income, expenditure, savings, and investment. Econ $51: 216-233$

Powell M, Round J (2000) Structure and linkage in the economy of Ghana: a SAM approach. In: Aryeetey E, Harrigan J, Nissanke M (eds) Economic reforms in Ghana: miracle or mirage. James Currey Press, Oxford, pp 68-87

Pyatt G, Round J (1979) Accounting and fixed price multipliers in a SAM framework. Econ J 89:850-873

Pyatt G, Round JI (2012) Distributional invariance and the design of SAMs. Econ Syst Res 24(3):251-273

Pyatt G, Thorbecke E (1976) Planning techniques for a better future. International Labour Office, Geneva

Quesnay F (1759) Tableau Economique. McMillan, London

Ramanathan R (1982) Cambridge growth models. Introduction to the theory of economic growth. Springer, Berlin, pp 220-243

Resosudarmo BP, Thorbecke E (1996) The impact of environmental policies on household incomes for different socioeconomic classes: the case of air pollutants in Indonesia. Ecol Econ 17(2):83-94

Round J (2003) Constructing SAMs for development policy analysis: lessons learned and challenges ahead. Econ Syst Res 15(2):161-183

Stone R (1947) Definition and measurement of the national income and related totals measurement of national income and construction of social accounts. United Nations, Geneva

Stone R, Brown A (1962) A computable model for economic growth. Cambridge Growth Project, Cambridge

Stone RA, Brown A et al (1962) A social accounting matrix for 1960. A program for growth. Chapman and Hall, London

Tarp F, Roland-Holst D et al (2002) Trade and income growth in Vietnam: estimates from a new social accounting matrix. Econ Syst Res 14(2):157-184

Thorbecke ER (1992) Adjustment and equity in Indonesia. OECD Development Centre, Paris

UN (2013) Women in Iraq Factsheet. http://www.jauiraq.org/documents/1628/Women\%20In\%20Iraq\%20Fact\%20 sheet\%20-\%20English.pdf. Retrieved 13 Feb 2014

Xie J (2000) An environmentally extended social accounting matrix. Environ Resour Econ 16:391-406 